\title{
Allochromatium renukae sp. nov.
}

Correspondence
Ch. Sasikala
r449@sify.com
or
sasi449@yahoo.ie

Correspondence

Ch. Sasikala

or

sasi449@yahooie

\author{
P. Anil Kumar, ${ }^{1}$ T. N. R. Srinivas, ${ }^{1}$ Ch. Sasikala ${ }^{1}$ and Ch. V. Ramana ${ }^{2}$ \\ ${ }^{1}$ Bacterial Discovery Laboratory, Centre for Environment, Institute of Science and Technology, \\ J. N. T. University, Kukatpally, Hyderabad 500 085, India \\ ${ }^{2}$ Department of Plant Sciences, School of Life Sciences, University of Hyderabad, P.O. \\ Central University, Hyderabad 500 046, India
}

At the time of writing, the genus Allochromatium comprises three recognized species, namely Allochromatium vinosum, Allochromatium minutissimum and Allochromatium warmingii, reclassified from Chromatium by Imhoff et al. (1998). In the present communication, we describe a novel species of the genus Allochromatium, isolated from brackish water in India.

Strain JA136 ${ }^{\mathrm{T}}$ was isolated from photolithoheterotrophic enrichments of an anoxic sediment and water sample taken from a brackish water body at Chollangi, Kakinada, India. Purification and polyphasic taxonomic studies were carried out as described previously (Anil Kumar et al., 2007a, b). In vivo absorption spectra were measured with a Spectronic Genesys 2 spectrophotometer in sucrose solution (Trüper \& Pfennig, 1981). Absorption spectra were also recorded from pigments extracted with acetone by eluting the cell suspension with acetone through a $10 \times 200$ - mm column packed with aluminium oxide. The carotenoid present was detected by comparing with the absorption maxima of

The GenBank/EMBL/DDBJ accession number for the 16S rRNA gene sequence of strain $\mathrm{JA} 136^{\top}$ is $\mathrm{AM} 399029$.

An electron micrograph of an ultrathin section of a cell of strain $\mathrm{JA} 136^{\top}$ and a figure showing the whole-cell absorption spectrum and acetone spectrum of pigments of strain $\mathrm{JA} 136^{\top}$ are available as supplementary material with the online version of this paper. standards from Britton et al. (2004). Sequences were aligned by using the program CLUSTAL_x (Thompson et al., 1997) and the alignment was corrected manually. The CLUSTAL_X alignment file was used as the input file to the program SEQBOOT in the PHYLIP package (Felsenstein, 1993) and the output file of SEQBOOT was used as the input file for maximum-likelihood analysis with 100 data sets and five times jumbling. A single tree was produced from 100 trees generated during maximum-likelihood analysis by using the program CONSENSE. A final dendrogram with evolutionary distances was constructed by taking the alignment .phy file as the infile and the consensus tree as the intree in the maximum-likelihood program within the PHYLIP package.

The sample (anoxic sediment along with water) yielding strain JA136 ${ }^{\mathrm{T}}$ was collected on 11 January 2006 from a brackish water body at Chollangi, Kakinada, India ( $16^{\circ} 54^{\prime}$ $\mathrm{N} 82^{\circ} 14^{\prime} \mathrm{E}$ ). The sample had a pH of 6.8 , salinity of $1 \%$ and a temperature of $30{ }^{\circ} \mathrm{C}$. Individual cells of strain JA136 ${ }^{\mathrm{T}}$ were ovoid to rod-shaped, $2.0-2.5 \times 3.0-5.0 \mu \mathrm{m}$ in size, multiplied by binary fission (Fig. 1) and were motile by means of a single polar flagellum. Electron microscopy of ultrathin sections of cells revealed vesicular-type internal membrane structures (see Supplementary Fig. S1 in IJSEM Online). Strain JA136 ${ }^{\mathrm{T}}$ was able to grow photolithoautotrophically [anaerobically, $2400 \mathrm{~lx}$, with $\mathrm{Na}_{2} \mathrm{~S} .9 \mathrm{H}_{2} \mathrm{O}$ 


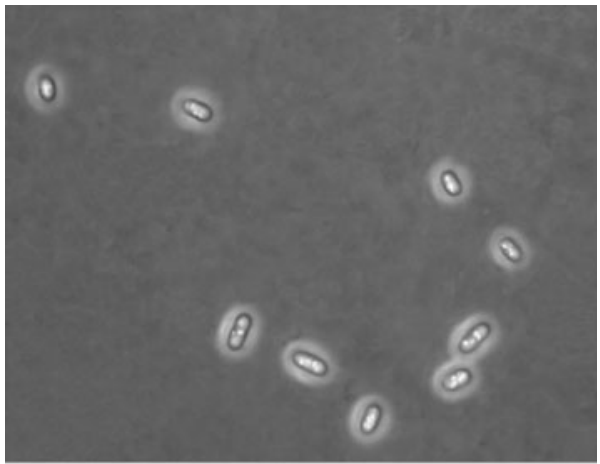

Fig. 1. Phase-contrast micrograph of cells of strain $\mathrm{JA} 136^{\top}$. Cells are $2-2.5 \mu \mathrm{m}$ long.

$(1 \mathrm{mM})$ and $\left.\mathrm{NaHCO}_{3}(0.1 \%, \mathrm{w} / \mathrm{v})\right]$ and photolithoheterotrophically [anaerobically, $2400 \mathrm{~lx}$, with $\mathrm{Na}_{2} \mathrm{~S} .9 \mathrm{H}_{2} \mathrm{O}$
$(1 \mathrm{mM}), \mathrm{NaHCO}_{3}(0.1 \%, \mathrm{w} / \mathrm{v})$ and sodium pyruvate $(0.3 \%, w / v)$ as an organic carbon source]. Photoorganoheterotrophy [anaerobically, $2400 \mathrm{~lx}$, with sodium pyruvate $(0.3 \%, \mathrm{w} / \mathrm{v})$ ], chemolithoautotrophy [aerobically, in the dark, with thiosulfate $(5 \mathrm{mM})$ and $\mathrm{NaHCO}_{3}(0.1 \%$, $\mathrm{w} / \mathrm{v})$ ], chemo-organoheterotrophy [aerobically, in the dark, with sodium pyruvate $(0.3 \%$, w/v)] and fermentative growth [anaerobically, in the dark, with glucose $(0.3 \%$, w/v)] could not be demonstrated. Organic substrates utilized for photo-organoheterotrophic growth (Table 1) in the presence of bicarbonate $(0.1 \%, \mathrm{w} / \mathrm{v})$ and $0.5 \mathrm{mM}$ $\mathrm{Na}_{2} \mathrm{~S} .9 \mathrm{H}_{2} \mathrm{O}$ were acetate, butyrate, pyruvate, fumarate, succinate, malate, glucose and Casamino acids. Substrates that could not be utilized by strain $\mathrm{JA}_{136^{\mathrm{T}}}$ included formate, propionate, lactate, fructose, ethanol, propanol, glycerol, glycolic acid, valerate and crotonate. $\mathrm{Na}_{2} \mathrm{~S} .9 \mathrm{H}_{2} \mathrm{O}$ was required for growth of strain $\mathrm{JA} 136^{\mathrm{T}}$, with optimum growth at a concentration of $2 \mathrm{mM} \cdot \mathrm{Na}_{2} \mathrm{~S} \cdot 9 \mathrm{H}_{2} \mathrm{O}$ was utilized as an electron donor (growth was very weak) under

Table 1. Differential characteristics between strain $\mathrm{JA} 136^{\top}$ and recognized species of the genus Allochromatium

Data for reference species were taken from Imhoff $(2005) .+$, Substrate utilized or present; - , substrate not utilized or absent; \pm , variable; $(+)$, weak growth; NR, not reported. All organisms are motile and are able to utilize acetate and pyruvate, but unable to utilize fructose, ethanol, propanol or glycerol. Organic substrate utilization was tested during photo-organoheterotrophic growth in the presence of $(0.1 \%$, w/v) bicarbonate and $0.5 \mathrm{mM} \mathrm{Na}_{2} \mathrm{~S} .9 \mathrm{H}_{2} \mathrm{O}$.

\begin{tabular}{|c|c|c|c|c|}
\hline Characteristic & Strain JA136 ${ }^{\mathrm{T}}$ & A. vinosum & A. minutissimum & A. warmingii \\
\hline Cell size $(\mu \mathrm{m})$ & $2.0-2.5 \times 3.0-5.0$ & $2.0 \times 2.5-6.0$ & $1.0-1.2 \times 2.0$ & $3.5-4.0 \times 5.0-11.0$ \\
\hline Carotenoid group & Lycopene & Spirilloxanthin & Spirilloxanthin & Rhodopinal \\
\hline DNA G $+C$ content $(\mathrm{mol} \%)$ & 62.3 (HPLC) & $61.3-66.3$ & 63.7 & $55.1-60.2$ \\
\hline $\mathrm{B}_{12}$ requirement & - & - & - & + \\
\hline Chemolithotrophic growth & - & + & + & - \\
\hline pH optimum (range) & $7.2-8.0(6.8-8.5)$ & $7.0-7.3(6.5-7.6)$ & $7.0-7.3(6.5-7.6)$ & $7.0(6.5-7.3)$ \\
\hline Temperature optimum $\left({ }^{\circ} \mathrm{C}\right)$ & $28-32$ & $25-35$ & $25-35$ & $25-30$ \\
\hline Salt requirement & None $^{*}$ & None $^{*}$ & None & None \\
\hline \multicolumn{5}{|l|}{ Substrates used } \\
\hline Hydrogen & - & + & + & - \\
\hline Formate & - & + & + & - \\
\hline Propionate & - & + & + & NR \\
\hline Butyrate & $(+)$ & \pm & \pm & - \\
\hline Lactate & - & $\mathrm{NR}$ & $\mathrm{NR}$ & - \\
\hline Fumarate & + & + & + & - \\
\hline Succinate & + & + & + & - \\
\hline Malate & + & + & + & - \\
\hline Glucose & + & - & - & - \\
\hline Glycolate & - & + & + & - \\
\hline Crotonate & - & - & + & - \\
\hline Valerate & - & - & + & - \\
\hline
\end{tabular}

${ }^{*}$ Marine strains may tolerate low concentrations of $\mathrm{NaCl}$. 
photolithoautotrophic conditions at a minimum concentration of $0.5 \mathrm{mM}$, while $\mathrm{Na}_{2} \mathrm{~S}_{2} \mathrm{O}_{3} \cdot 5 \mathrm{H}_{2} \mathrm{O}$, sulfite, elemental sulfur and hydrogen did not support growth. $\mathrm{Na}_{2} \mathrm{~S} .9 \mathrm{H}_{2} \mathrm{O}$ was utilized as a sulfur source by strain $\mathrm{JA}_{136^{\mathrm{T}}}$, while $\mathrm{Na}_{2} \mathrm{~S}_{2} \mathrm{O}_{3} \cdot 5 \mathrm{H}_{2} \mathrm{O}$, sulfate, sulfite, thioglycolate, cysteine, elemental sulfur and methionine did not support growth. Ammonium chloride and molecular nitrogen were utilized as nitrogen sources, while nitrate, nitrite, urea, glutamate and glutamine did not support growth. There was no absolute salt requirement for growth but the strain was able to tolerate up to $4 \% \mathrm{NaCl}(\mathrm{w} / \mathrm{v})$. Strain JA136 ${ }^{\mathrm{T}}$ grew over the $\mathrm{pH}$ range $6.8-8.5$, with optimum growth at $\mathrm{pH} 7.2-8.0$. The optimum temperature for growth was $30{ }^{\circ} \mathrm{C}$ (range $25-30{ }^{\circ} \mathrm{C}$ ). There was no vitamin requirement for growth.

The photosynthetically grown cell suspension was purpleviolet in colour. The whole-cell absorption spectrum of strain $\mathrm{JA} 136^{\mathrm{T}}$ gave absorption maxima at $374,460,494$, 527, 590, 809 and $857 \mathrm{~nm}$, indicating the presence of bacteriochlorophyll $a$, and the absorption spectrum for pigments extracted with acetone gave absorption maxima at 448,475 and $505 \mathrm{~nm}$, indicating the presence of the carotenoid lycopene of the rhodopinal series (Supplementary Fig. S2). The DNA base composition of strain JA136 ${ }^{\mathrm{T}}$ was $62.3 \mathrm{~mol} \% \mathrm{G}+\mathrm{C}$ (by HPLC). The phylogenetic relationship of strain JA136 ${ }^{\mathrm{T}}$ to other purple sulfur bacteria was examined by $16 \mathrm{~S}$ rRNA gene sequence analysis. The data obtained revealed that the new isolate branched separately but clustered with the type strains of recognized species of the genus Allochromatium and was distinct from other genera of purple sulfur bacteria (Chromatiaceae). Strain JA136 ${ }^{\mathrm{T}}$ showed highest 16S rRNA gene sequence similarity to the type strains of $A$. vinosum (97.0\%), A. minutissimum $(95.8 \%)$ and A. warmingii $(90.0 \%)$ (Fig. 2). In addition to $16 \mathrm{~S}$ rRNA gene sequence dissimilarity, strain JA $136^{\mathrm{T}}$ showed clear phenotypic differences (cell shape, colour of cell suspension, carotenoid composition, sulfate assimilation, chemolithotrophic growth, carbon and electron donor utilization) from $A$. vinosum, $A$. minutissimum and $A$. warmingii (Table 1 ) that justify the description of this strain as representing a novel species of the genus Allochromatium. The name Allochromatium renukae sp. nov. is proposed for this organism.

\section{Description of Allochromatium renukae sp. nov.}

Allochromatium renukae [re' nu.kae. N.L. gen. n. renukae of Renuka, named in memory of Dr (Mrs) B. Renuka, an Indian microbiologist and our (Ch.V.R., Ch.S.) research supervisor, who initiated work on purple sulfur bacteria in India].

Cells are ovoid to rod-shaped, $2.0-2.5 \times 3.0-5.0 \mu \mathrm{m}$ in size, are motile by means of a single polar flagellum and divide by binary fission. Growth occurs under anaerobic conditions in the light (photolithoautotrophy and photolithoheterotrophy). Internal photosynthetic membranes are of the vesicular type. Phototrophic cultures are purple-violet in

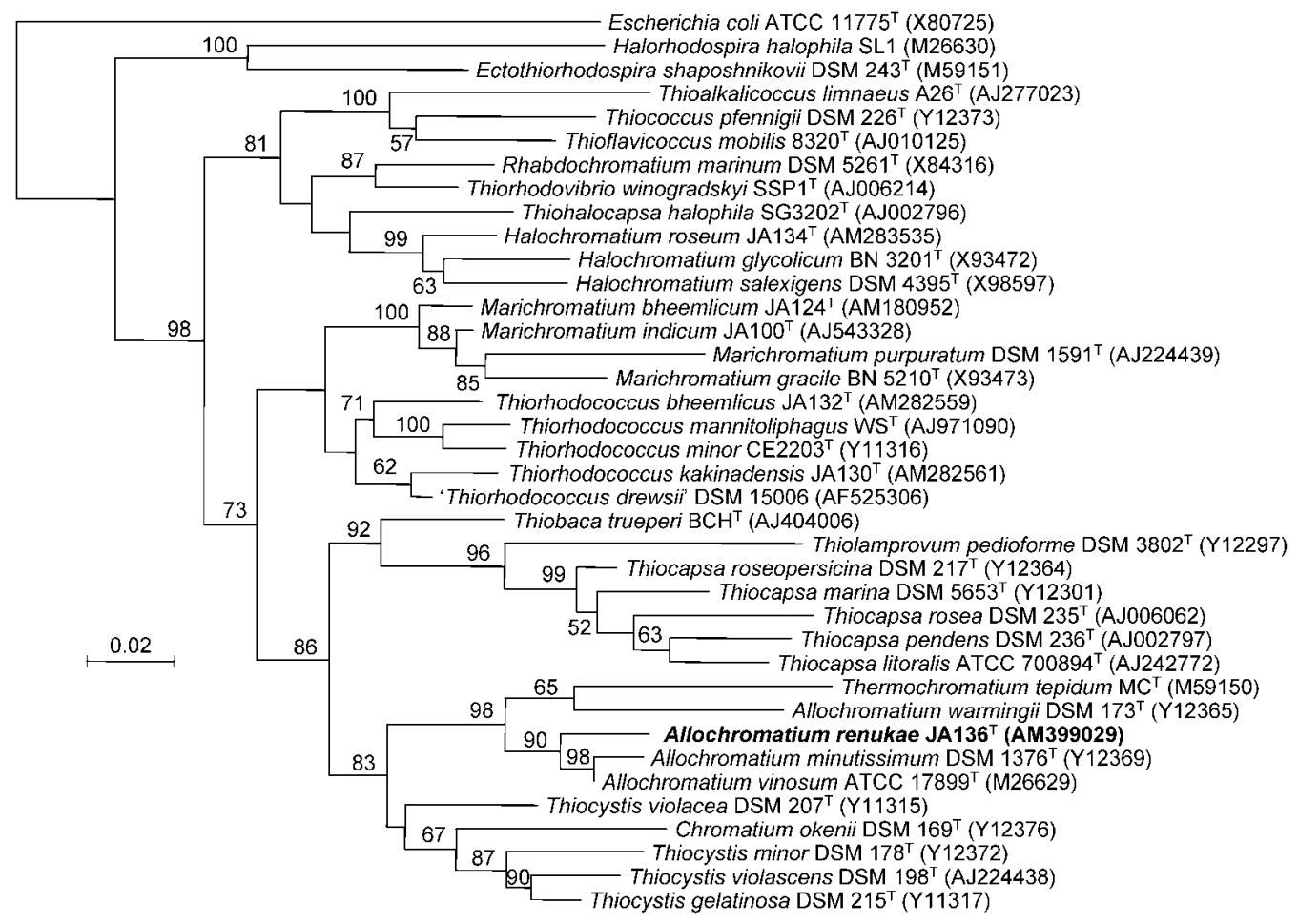

Fig. 2. Evolutionary-distance dendrogram showing the phylogenetic relationship of strain $J A 136^{\top}$ within the family Chromatiaceae based on 16S rRNA gene sequence analysis. Bar, 2 nucleotide substitutions per 100 nucleotides. 
colour. The in vivo absorption spectrum of intact cells in sucrose exhibits maxima at 374, 460, 494, 527, 590, 809 and $857 \mathrm{~nm}$, indicating the presence of bacteriochlorophyll $a$, and the absorption spectrum for pigments extracted with acetone has absorption maxima at 448, 475 and $505 \mathrm{~nm}$, indicating the presence of the carotenoid lycopene of the rhodopinal series. Growth is mesophilic $\left(30^{\circ} \mathrm{C}\right)$; optimum growth at $\mathrm{pH}$ 7.2-8.0. There is no absolute salt requirement for growth but it tolerates up to $4 \% \mathrm{NaCl}(\mathrm{w} / \mathrm{v})$. Photolithoheterotrophy with a few organic compounds is the preferred mode of growth. Good growth is observed with acetate, pyruvate, fumarate, succinate, malate and glucose as carbon sources. Growth also occurs with butyrate and Casamino acids. Photo-organoheterotrophy and chemotrophy are not observed. No growth factors are required. The DNA base composition is $62.3 \mathrm{~mol} \% \mathrm{G}+\mathrm{C}$ (by HPLC).

The type strain, JA136 ${ }^{\mathrm{T}}\left(=\mathrm{JCM} 14262^{\mathrm{T}}=\mathrm{DSM} 18713^{\mathrm{T}}\right)$, was isolated from a brackish water body at Chollangi, Kakinada, India.

\section{Acknowledgements}

Financial assistance was received from the Department of Biotechnology, Government of India. P. A. K. and T. N. R. S. acknowledge the CSIR, Government of India, for the award of SR fellowships.

\section{References}

Anil Kumar, P., Sasi Jyothsna, T. S., Srinivas, T. N. R., Sasikala, Ch., Ramana, Ch. V. \& Imhoff, J. F. (2007a). Marichromatium bheemlicum sp. nov., a non-diazotrophic photosynthetic gammaproteobacterium from a marine aquaculture pond. Int J Syst Evol Microbiol 57, 1261-1265.

Anil Kumar, P., Sasi Jyothsna, T. S., Srinivas, T. N. R., Sasikala, Ch., Ramana, Ch. V. \& Imhoff, J. F. (2007b). Two novel species of marine phototrophic Gammaproteobacteria: Thiorhodococcus bheemlicus sp. nov. and Thiorhodococcus kakinadensis sp. nov. Int J Syst Evol Microbiol 57, 2458-2461.

Britton, G., Liaaen-Jensen, S. \& Pfander, H. (2004). Carotenoids with a $\mathrm{C}_{40}$ skeleton. (a) Hydrocarbons. In Carotenoids Handbook, Main List 31. Edited by G. Britton, S. Liaaen-Jensen \& H. Pfander. Boston: Birkhauser.

Felsenstein, J. (1993). PHYLIP (phylogeny inference package), version 3.5.1. Department of Genome Sciences, University of Washington, Seattle, USA.

Imhoff, J. F. (2005). Genus II. Allochromatium Imhoff, Süling and Petri 1998b, $1140^{\mathrm{VP}}$. In Bergey's Manual of Systematic Bacteriology, 2nd edn, vol. 2, part B, pp. 12-14. Edited by D. J. Brenner, N. R. Krieg, J. T. Staley \& G. M. Garrity. New York: Springer.

Imhoff, J. F., Süling, J. \& Petri, R. (1998). Phylogenetic relationships among the Chromatiaceae, their taxonomic reclassification and description of the new genera Allochromatium, Halochromatium, Isochromatium, Marichromatium, Thiococcus, Thiohalocapsa and Thermochromatium. Int J Syst Bacteriol 48, 1129-1143.

Thompson, J. D., Higgins, D. G., Gibson, T. J., Plewniak, F., Jeanmougin, F. \& Higgins, D. G. (1997). The CLUSTAL_X windows interface: flexible strategies for multiple sequence alignment aided by quality analysis tools. Nucleic Acids Res 25, 4876-4882.

Trüper, H. G. \& Pfennig, N. (1981). Isolation of members of the families Chromatiaceae and Chlorobiaceae. In The Prokaryotes: a Handbook on Habitats, Isolation and Identification of Bacteria, pp. 279-289. Edited by M. P. Starr, H. Stolp, H. G. Trüper, A. Balows \& H. G. Schlegel. Berlin: Springer-Verlag. 